\title{
PENGARUH KEPEMIMPINAN PEMERINTAHAN DALAM INOVASI KEBIJAKAN LAYANAN PUBLIK DI KABUPATEN TULANG BAWANG
}

\author{
Winarti $^{1}$, Murtir Jeddawi ${ }^{2}$, Sampara Lukman $^{3}$, Agus Fatoni ${ }^{4}$ \\ ${ }_{1,2,3,4}$ Institut Pemerintahan Dalam Negeri (IPDN) \\ Email: winartitulang1@gmail.com
}

\begin{abstract}
Abstrak
Kualitas layanan publik merupakan parameter utama dalam keberhasilan suatu daerah otonomi mengimplementasikan desentralisasi. Kepemimpinan merupakan dimensi yang sangat penting dalam kualitas layanan publik. Dengan adanya inovasi dari pemimpin atau kepala daerah dapat meningkatkan kualitas layanan publik didaerah tersebut. Dengan demikian tujuan penelitian ini adalah meneliti pengaruh kepemimpinan pemerintahan dalam inovasi kebijakan layanan public di Kabupaten Tulang Bawang Lampung yang dapat meningkatkan kualitas layanan. Penelitian ini menggunakan metode campuran atau sering disebut dengan mixed method dengan metode eksplanatoris sekuensial. Hasil penelitian menunjukkan kepemimpinan pemerintahan menunjukkan kepemimpinan pemerintahan berpengaruh kuat kepada pelayanan publik. Dari temuan penelitian terungkap bahwa hampir seluruh dimensi dari variabel kepemimpinan pemerintahan memiliki pengaruh yang dominan yang disebabkan oleh besarnya peran pemimpin bagi para pegawainya dimana seorang pemimpin dapat memberikan pengaruh dan mempengaruhi tingkah pola pegawai atau bawahannya sehingga jika ada inovasi layanan public dari kepala daerah dapat memberikan pengaruh yang signifikan kepada kualitas layanan.
\end{abstract}

Kata Kunci: Kepemimpinan Pemerintahan, Inovasi Kebijakan, Pelayanan Publik.

\section{Abstract}

The quality of public services is the main parameter in the success of an autonomous region in implementing decentralization. Leadership is a very important dimension in the quality of public services. With the innovation of the leader or regional head, it can improve the quality of public services in the area. Thus the purpose of this study is to examine the influence of government leadership in public service policy innovation in Tulang Bawang Lampung Regency which can improve service quality. This research uses a mixed method or often referred to as a mixed method with a sequential explanatory method. The results showed that government leadership had a strong influence on public services. From the research findings, it is revealed that almost all dimensions of government leadership variables have a dominant influence due to the large role of the leader for employees where a leader can influence and influence the behavior of employees or subordinates so that if there is public service innovation from the regional head it can have an influence service quality.

Keywords: Government Leadership, Innovation Policy, Public Services.

\section{A. PENDAHULUAN}

Pelayanan publik menjadi ukuran performa pemerintah yang paling terlihat.

Masyarakat secara langsung menilai efisiensi pemerintah berdasarkan kualitas pelayanan 
publik yang diberikan, dan kualitas pelayanan publik dirasakan oleh semua lapisan masyarakat, dimana pencapaian dalam membangun kinerja pelayanan publik adalah kompeten, handal, efisien dan akuntabel. Dengan begitu, di mata masyarakat akan mengangkat citra positif pemerintah di mata warganya (Dwiyanto, 2001; Wirijadinata, 2020).

Peran kepemimpinan merupakan salah satu upaya untuk meningkatkan kualitas pelayanan publik (Setiadi, 2018; Syahrian, 2019). Contoh penerapan otonomi daerah yang efektif di berbagai daerah otonom adalah apakah standar pelayanan publik ada di setiap daerah otonom tersebut. (Sugiyanto, 2013). Hingga saat ini, pelayanan publik tetap menjadi tolak ukur utama keberhasilan Daerah Otonom mengadopsi struktur desentralisasi, dimana keberhasilan setiap masyarakat otonom dalam meningkatkan kualitas pelayanan publik sangat berbeda-beda. (Andiri, 2015). Keberagaman sangat dipengaruhi oleh kreativitas dalam kepemimpinan kepala daerah atau masyarakat otonom. Dengan kemajuan yang telah dilakukan, setiap pengelola daerah atau kepala daerah memiliki karakteristik yang berbedabeda dalam menangani segala peluang yang ada di daerah untuk memberikan peningkatan standar pelayanan (Djamaludin, 2012). Situasi ini menyebabkan peningkatan tingkat pelayanan publik di masing-masing negara. Kreativitas seorang pemimpin juga akan berdampak kuat pada peningkatan efisiensi pelayanan publik dalam masyarakat yang mandiri (Hidayat \& Permana, 2017).

Pemimpin yang inovatif adalah pemimpin yang memiliki gaya kepemimpinan sebagai gaya kolaboratif yang tidak hanya mengambil keputusan dari sudut pandangnya, tetapi mengumpulkan semua gagasan dari seluruh pekerja untuk melaksanakan musyarawah dan memutuskan bersama (Paramita, 2011). Artinya, menjadi pemimpin yang inovatif adalah melalui gaya kepemimpinan yang dianut oleh pemimpin. Pemimpin dan kreativitas adalah dua hal yang harus berjalan seiring. Dengan kata lain, ketika ada pemerintah, ada perkembangan dan strategi dan proposal inovatif untuk pembangunan dan transformasi. Untuk itu, pemimpin harus mengetahui bagaimana membaca dan meneliti konteks dan kondisi kelembagaan organisasi yang dipimpinnya (Masambe et al, 2015)..

Di era global saat ini, kepemimpinan inovasi harus mengalami perbaikan sejalan dengan inovasi lingkungan (Adair, 2007). Selain itu, terdapat tiga jenis perubahan terkait masalah kepemimpinan, yaitu reformasi rutin, perubahan perkembangan, dan inovasi itu sendiri (Putri et al, 2019). Kenyataannya, penanganan transisi itu sulit. Indikator kemampuan memimpin seseorang adalah kemampuannya dalam menghadapi transisi (Resdiana, 2016). Kemampuan ini sangat penting karena pada saat ini para pemimpin diharapkan mampu 
memajukan lingkungan hidup. Kepemimpinan terkait dengan kapasitas individu untuk membujuk orang agar melakukan apa yang diinginkan oleh seorang pemimpin (Siagian, 2002). Salah satu jenis upaya yang dapat dilakukan untuk menanggapi era global ini adalah memungkinkan seorang pemimpin menemukan cara-cara inovatif untuk mengoptimalkan daya saing dan kinerja. Hal ini harus dicapai dalam arti ekspektasi demokrasi yang sangat beragam dan meningkatnya kebutuhan akan sumber daya publik, yang berarti bahwa standar optimal pemerintahan yang baik membutuhkan upaya yang serius (Siagian, 1982). Sementara di sisi lain, tuntutan kebutuhan masyarakat yang harus dipenuhi oleh birokrasi sangat beragam dan jumlahnya terus meningkat, di samping tingkat kesadaran masyarakat yang semakin tinggi. Situasi ini menuntut lembaga publik untuk bersedia melakukan perbaikan sistemik yang signifikan untuk tata kelola pemerintahan yang baik (Nawawi, 2003).

Variabel kinerja ini penting untuk analisis karena difokuskan pada penjelasan mengapa hasil kinerja yang diberikan kepada lingkungan akan bergantung pada tingkat kinerja. Artinya organisasi birokrat pemerintah tidak dapat meningkatkan transparansi, kepercayaan, keadilan, produktivitas eksternal dan kepuasan warga sebagai tolak ukur keberhasilan eksternal tanpa kinerja internal yang baik. Peningkatan kualitas pelayanan publik untuk meningkatkan kinerja organisasi dapat dicapai melalui kepemimpinan pemerintah dengan paradigma baru yang memiliki prinsip inovatif. Agar organisasi dapat bekerja secara efisien, seorang pemimpin yang berpikir harus memenuhi dua peran kunci, yaitu fungsi kolektif berbasis tugas dalam bentuk strategi pelayanan publik. Dalam hal ini, hubungan antara kepemimpinan pemerintah di Kabupaten Tulangawang dengan implementasi kebijakan Bergerak Melayani Warga (BMW) belum pernah dikaji sebelumnya. Belum pernah sebelumnya bentuk kebijakan yang efektif dan efisien diidentifikasi dalam layanan publik.

Atas dasar definisi diatas maka penulis tertarik untuk melakukan penelitian dengan judul: Pengaruh Kepemimpinan Pemerintah terhadap Inovasi Kebijakan Pelayanan Publik di Kabupaten Tulang Bawang. Penelitian ini bermanfaat untuk mengetahui, menganalisis dan menjelaskan kepemimpinan pemerintah dalam menciptakan pelayanan publik yang efisien di Kabupaten Tulang Bawang.

\section{B. METODE}

Sehubungan dengan penelitian dalam artikel ini, peneliti menggunakan penelitian campuran dengan serangkaian metode eksplanatori (Creswell \& Creswell, 2017). Penelitian 
metode campuran, atau sering disebut dengan mixed-method, adalah suatu metode riset yang menggabungkan dan menghubungkan bentuk kuantitatif dan kualitatif dengan proses penalaran induktif-deduktif, yaitu mempelajari sesuatu yang bersifat umum dan kemudian memecahnya menjadi bentuk tertentu. yaitu bentuk tertentu kemudian diekstraksi, yang menjadi bentuk umum berdasarkan teori sesuai dengan peristiwa dan kebutuhan penelitian (Effendy, 2010).

Metode interpretasi sekuensial merupakan metode yang digunakan pada tahap pertama dengan mengumpulkan dan menganalisis data kuantitatif, kemudian pada tahap kedua dengan mengumpulkan dan menganalisis data kualitatif berdasarkan hasil kuantitatif awal. Hal pertama yang perlu dilakukan peneliti adalah memberikan gambaran kepemimpinan pemerintah melalui kebijakan "Bergerak Melayani Warga" untuk meningkatkan efisiensi pelayanan melalui inovasi pelayanan publik dengan menggunakan riset digital. Kemudian setelah mendapatkan informasi di atas, peneliti melanjutkan penelitian kualitatif untuk mengkaji topik ini lebih dalam. Oleh karena itu, desain penelitian campuran ini menggunakan serangkaian strategi penjelas. Tujuan dari desain penelitian ini adalah untuk mengidentifikasi data berdasarkan hasil kuantitatif dan mempelajarinya secara lebih mendalam dengan menggunakan data kualitatif.

\section{HASIL DAN PEMBAHASAN}

\section{Hasil Penelitian Kuantitatif}

Data penelitian kuantitatif dilakukan untuk mengungkap pertanyaan peneliti, “Apa peran kepemimpinan pemerintah dalam pelayanan publik di wilayah Tulang Bawang. Analisis Deskriptif digunakan dalam penelitian ini. Analisis ini dimaksudkan untuk memberikan gambaran tentang data yang dikumpulkan tanpa mencapai kesimpulan umum atau generalisasi.

Penjelasan dan interpretasi variabel didasarkan pada agregasi berbagai dimensi dan metrik, dan kemudian dianalisis berdasarkan analisis data primer dan sekunder. Pengukuran variabel uji dihitung berdasarkan mood responden, interpretasi atau pendapat masing-masing fitur query, dan hasilnya diolah dalam bentuk tabel frekuensi. Pengukuran dilakukan dengan menggunakan kuesioner untuk menilai status variabel yang diamati. Kuesioner untuk variabel $\mathrm{X}$ adalah tata kelola dan variabel $\mathrm{Y}$ (pelayanan publik) sebanyak 52 pertanyaan yang masingmasing memiliki 5 pilihan dan menurut responden. Hasil jawaban responden yaitu skor tiap item yang diambil dari total nilai masing-masing item pertanyaan memperoleh 160 gabungan 
tanggapan, yang kemudian dinilai sesuai dengan kriteria penilaian dengan menggunakan set skor ideal sebagai berikut: dengan Jumlah responden $=160$ orang, nilai skala pengukuran terbesar $=5$, sedangkan skala pengukuran minimum $=1$, sehingga nilai maksimum angka kumulatif $=160 \times 5=800$ dan nilai minimum angka kumulatif $=160 \times 1=160$.

a. Rentang poin tertinggi dan terkecil adalah 800-160 $=640$.

b. Area penilaian untuk setiap kategori adalah $640 / 5=128$

Kemudian didapatkan kriteria penilaian rata-rata skor dari tabel dibawah ini:

Tabel 1 Kriteria Penilaian Berdasarkan Rata-Rata Skor

\begin{tabular}{|c|l|}
\hline Rentang Skor & \multicolumn{1}{c|}{ Kategori } \\
\hline $160-228$ & Sangat Buruk \\
\hline $229-357$ & Tidak Baik \\
\hline $358-486$ & Kurang Baik \\
\hline $487-615$ & Baik \\
\hline $616-640$ & Sangat Baik \\
\hline
\end{tabular}

Berdasarkan kategori pada Tabel 1, maka diperoleh persepsi kepemimpinan dan perkembangan Kabupaten Tulang Bawang pada penyelenggara pemerintahan di provinsi Lampung melalui angket kepemimpinan yang berisi sebanyak 11 statement. Nilai terendah per item adalah 1 dan nilai tertinggi 5 (lima alternatif jawaban). Jika dicapai rentang nilai 160 sampai 640, variabel kepemimpinan di Kabupaten Tulang Bawang secara umum dinilai baik dengan nilai 577. Artinya kepemimpinan pemerintahan yang diterapkan harus tetap dipertahankan dan ditingkatkan dalam pelaksanaan fungsi sehari-harinya. . Artinya, penerapan tiga dimensi paling baik. Data tersebut secara empiris menunjukkan bahwa nilai rata-rata secara teori lebih tinggi yang berarti bahwa kepemimpinan Gubernur dalam penyelenggaraan Pemerintahan dan Pembangunan Kabupaten Tulang Bawang di Negara Lampung sudah berjalan dengan baik.

Tabel 2 Kategorisasi Persepsi Pegawai Terkait Kepemimpinan Pemerintahan di Kabupaten Tulang Bawang

\begin{tabular}{|c|l|c|}
\hline Rentang Skor & \multicolumn{1}{|c|}{ Kategori } & Frekuensi \\
\hline $24-42$ & Sangat Rendah & 0 \\
\hline $43-60$ & Rendah & 0 \\
\hline $61-78$ & Tinggi & 97 \\
\hline $79-96$ & Sangat Tinggi & 63 \\
\hline \multicolumn{2}{|c|}{ Total } & $\mathbf{1 6 0}$ \\
\hline
\end{tabular}

Tabel 2 menunjukkan persepsi pegawai terhadap kepemimpinan pemerintah di Kabupaten Tulang Bawang. Hasil penelitian ini menunjukkan bahwa $40 \%$ pegawai menilai kepemimpinan pemerintahan di Kabupaten Tulang Bawang terlalu tinggi dan $60 \%$ pegawai menilai kepemimpinan pemerintahan termasuk tingkat tinggi. Data ini menegaskan bahwa 
secara keseluruhan kepemimpinan pemerintah berada pad alevel tinggi dan sangat tinggi dalam pengelolaan dan pembangunan pemerintahan Kabupaten Tulang Bawang Provinsi Lampung; Artinya, kepemimpinan pemerintahan yang ditunjukkan oleh presiden kabupaten berjalan dengan sangat baik.

Secara umum kepemimpinan pemerintah dalam pengelolaan dan pembangunan Kabupaten Tulang Bawang Provinsi Lampung dapat dilihat berdasarkan: (1) motivasi inspirasi, (2). Efek individu, (3). Penilaian individu dan (4) stimulasi intelektual.

Kepemimpinan pemerintahan yang telah berjalan dengan sangat baik di Kabupaten Tulang Bawang ini sesuai dengan penelitian yang dilakukan oleh Septianti (2017), yaitu bahwa Adanya pengaruh positif yang signifikan pada variabel kepemimpinan pemerintahan terhadap kinerja pelayanan publik sangat mungkin disebabkan oleh besarnya peran pemimpin bagi para pegawainya dimana seorang pemimpin dapat memberikan pengaruh dan mempengaruhi tingkah pola pegawai atau bawahannya.

\section{Hasil Analisa Kualitatif}

Kepemimpinan itu sendiri dirancang untuk mempengaruhi individu untuk mencapai tujuan bersama. Kepemimpinan mempengaruhi orang, mengidentifikasi dan menangani apa yang perlu dicapai dan bagaimana kegiatan dilakukan secara efisien, serta mekanisme untuk memfasilitasi pengguna individu dan kelompok untuk mencapai tujuan bersama (Yukl, 1998).

Kepemimpinan yang baik dalam pemerintahan bagi bawahan adalah jujur, bijak dan mau turun sebagai bawahan, sehingga bawahan merasa diterima oleh pimpinannya, Pemimpin harus mempertimbangkan nasihat atau umpan balik dari bawahan, karena bawahan mereka sangat penting bagi suatu entitas atau departemen, dibawahnya tidak merasa diremehkan dengan saran atau kontribusi atasan, jelas bawahan melakukan pekerjaan yang disuruh, dan apabila ada permasalahan dengan karyawan, jika bersifat pribadi maka pimpinan sendiri yang menangani dan mencarikan solusi terbaik (Kadis Education).

Cara pemimpin menyelesaikan masalah karyawan dengan karyawan lain adalah dengan memanggil pihak-pihak yang kemudian akan mencari solusi terbaik. Pimpinan pemerintahan di Kabupaten Tulang Bawang terbuka dan memperhatikan bawahannya. Untuk meningkatkan kinerja pegawai, pimpinan di kantor ini memberikan contoh tetap menjalankan tugas tidak hanya berbicara atau menasihati anggota (Kadis PU). 
Kepemimpinan yang baik mampu mencapai tujuan yang telah ditetapkan, sehingga kelembagaan dilaksanakan dengan gerakan dari pimpinan. Seorang pemimpin yang sulit ditemukan, sulit berkomunikasi dengan mereka yang menolak tujuan badan yang dicapai karena sama saja yang menjauh dari bawah. Saran dari bawahan kepada instansi dipersilahkan tetapi dipilih dulu, jika benar baik untuk lembaga yang dijalankan atau dijalankan. Untuk meningkatkan kinerja liontin, senada dengan whistleblower lain yang dinasehati, motivasi karyawan dapat membawa hal-hal yang positif (Kadis Pera dan waskim).

Pemimpin yang baik yang berdiri teguh, memahami bawahannya, dan melihat arah perubahan organisasi yang dinamis. Menurut informasi lain, peningkatan kinerja kepemimpinan disini memberikan motivasi yang lebih bagi karyawan untuk memberikan kinerja yang baik bagi organisasi dan sebagai cara untuk memperhatikan kebutuhan karyawan jika terjadi perubahan dalam organisasi. (Ka BPKAD).

Berdasarkan hasil penelitian yang diperoleh peneliti, bahwa kepemimpinan pemikiran yang diterapkan oleh Bupati Tulang Bawang ini benar-benar unggul dan berkualitas. Untuk mewujudkan hal tersebut, Bupati Tulang Bawang berupaya keras untuk menciptakan perubahan yang lebih baik, jelas yang usahanya adalah pengabdian masyarakat yang mudah. Agar Hasil dan tujuan tercapai, maka diperlukan kepatuhan yang baik dari seluruh pegawai Kabupaten Tulang Bawang. Karena kedisiplinan yang baik merupakan tanggung jawab yang sangat besar bagi seseorang atas pekerjaan yang diamanatkan. Ini akan menumbuhkan semangat atau moral dan pencapaian tujuan organisasi.

Untuk membawa perubahan positif, salah satu kebijakan peraih penghargaan Kabupaten Tulang Bawang adalah menciptakan inovasi yang mempermudah kegiatan pemerintah dalam program BMW 25 guna mencapai tujuan yang telah dicapai tujuan pengabdian kepada masyarakat. Dengan memberikan perbaikan dalam melayani semua orang di distrik yang dia kendarai, dari arus ke bawah, dengan segala macam inovasi. Agar pelayanan dapat terlaksana dengan cepat dan efisien, harapan seluruh masyarakat Kabupaten Tulang Bawang dapat terwujud dengan harapan kepuasan masyarakat.

Demi kesejahteraan masyarakat, Bupati Tulang Bawang berupaya menjadi pemimpin yang baik. Berbagai inovasi yang ia terapkan dalam manajemen pelayanan publik salah satunya adalah program Bergerak Melayani Warga (BMW). BMW adalah inovasi manajemen yang bertujuan untuk menyederhanakan, mempercepat, mempercepat, dan mendekatkan layanan publik kepada komunitas yang baik karena faktor geografis yang 
diakibatkan oleh struktur yang tidak memadai. BMW merupakan program kebijakan / kegiatan prioritas untuk 5 (lima) tahun ke depan yang akan dilaksanakan secara berkala.

Di Indonesia, kuantitas (akses) dan kualitas pelayanan publik masih lemah (tidak memadai) baik dari segi kebutuhan masyarakat maupun harapan saat ini (jika ditentukan). Di Indonesia, banyaknya permasalahan pelayanan publik khususnya di Kabupaten Tulang Bawang terkait dengan rendahnya tingkat pelayanan publik menjadi salah satu sorotan pemerintah birokrasi dalam memberikan pelayanan kepada masyarakat. Peningkatan pelayanan publik pada masa reformasi merupakan dambaan setiap orang, namun hal ini tidak berubah drastis. Tanggapan dari berbagai opini publik biasanya menunjukkan bahwa berbagai bentuk layanan publik telah menurun di negara tersebut, dengan berbagai anomali dalam layanan publik tersebut (Wahyudi, 2015). Struktur dan proses penyampaian yang berbelit-belit, serta kecepatan lambannya sumber daya manusia dalam pengadaan fasilitas, dikunci, ditutup, tidak setara, dan mendidik tidak hanya untuk mewakili tetapi juga untuk melayani aspek layanan publik yang diterangi secara luas (Adiwisastra, 2001). Rendahnya kualitas pelayanan publik yang diberikan oleh berbagai pejabat atau penyelenggara pemerintahan terpilih dalam menjalankan peran dan fungsinya. Penjelasan dari situasi ini adalah, mengingat sistem hukum administrasi pemerintahan yang optimis di Indonesia, persyaratan pelayanan sudah diatur, tetapi standar pelayanan publik tersebut belum diterapkan dalam pelaksanaan fungsi pemerintahan (Blau, 1956).

Menciptakan disiplin bagi bawahan dapat dilakukan dan dikembangkan dengan berbagai cara. Antara lain yaitu motivasi, pendidikan dan pelatihan, kepemimpinan, kesejahteraan dan ketaatan pada disiplin. Mendidik pegawai secara rutin dengan meningkatkan disiplin, menjaga emosi, menepati janji, setiap melakukan pekerjaan yang konsisten, adil dan teliti, bukan hal yang mustahil bagi pimpinan pemerintahan untuk mendidik pegawai di Kabupaten Tulang Bawang sekaligus mengedukasi pegawai tentang peningkatan disiplin karena kurangnya sanksi manajemen yang berat dan kurangnya disiplin atau kesadaran karyawan.

\section{KESIMPULAN}

Model Kepemimpinan Pemerintahan dalam Inovasi Pelayanan Publik di Kabupaten Tulang Bawang dengan program Bergerak Melayani Warga berdasarkan hasil survey dan wawancara diperoleh hasil bahwa kepemimpinan pemerintahan di Kabupaten Tulang Bawang sesuai dengan teori model kepemimpinan yaitu model kepemimpinan 
transformasional. Kepemimpinan Pemerintahan terhadap Pelayanan Publik di Kabupaten Tulang Bawang melalui hasil penelitian berpengaruh signifikan terhadap pelayanan publik (Effectiveness of Public Services).

Kepemimpinan dibawah kepala daerah dalam rangka keberhasilan pelayanan publik sebaiknya tidak hanya bergantung kepada peran dari Bupati akan tetapi peran dan dukungan dari pimpinan tingkat menengah dibawah Bupati seperti Kepala-kepala Dinas, Kepala bagian maupun Kepala Bidang harus terlibat aktif berperan serta dalam hal mengimplementasikan kebijakan Bergerak Melayani Warga (BMW) dalam rangka memberikan pelayanan yang optimal kepada publik. Meskipun satu orang pemimpin cerdas, pintar dan inovatif akan tetapi apabila tidak didukung oleh aparat-aparat dibawah jajarannya maka pelayanan yang diberikan kepada masyarakat tentu tidak akan berjalan optimal dan memuaskan.

Meningkatkan pelayanan publik di Kabupaten Tulang Bawang tidak hanya diharapkan peran internal dari aparatur pemerintah tetapi juga harus adanya peran dari masyarakat itu sendiri. Diharapkan masyarakat lebih bekerja sama untuk mengawasi kinerja pegawai serta melaporkan setiap adanya kejanggalan yang terjadi.

\section{DAFTAR PUSTAKA}

Adair, J. E. (2007). Leadership for Innovation: How to Organize Team Creativity and Harvest Ideas. Kogan Page Publishers.

Adiwisastra, J. (2001). Penataan Kembali Birokrasi Pemerintahan Daerah Dalam Pelaksanaan Otonomi Daerah: Pidato Pengukuhan Jabatan Guru Besar Dalam Ilmu Perilaku Organisasi Pada Fakultas Ilmu Sosial Dan Ilmu Politik Unpad. Departemen Pendidikan Nasional UNPAD.

Andiri, S. A. (2015). Kualitas Pelayanan Transportasi Publik (Studi Deskriptif Tentang Kualitas Pelayanan Kapal Penumpang Trayek Gresik-Bawean di Pelabuhan Gresik). Sumber, 43, 31.

Blau, P. M. (1956). Bureaucracy in Modern Society. Random House.

Creswell, J. W., \& Creswell, J. D. (2017). Research Design: Qualitative, quantitative, and mixed methods approaches. Sage publications.

Djamaludin. (2012). Psikologi Kepemimpinan dan Inovasi. Penerbit Erlangga. Jakarta.

Dwiyanto, A. (2001). Penilaian Kinerja Organisasi Publik. Jurusan Ilmu Administrasi Negara, Fisipol UGM, Yogyakarta.

Effendy, K. (2010). Memadukan Metode Kuantitatif dan Kualitatif. Bandung: Indra Prahasta

Hidayat, A., \& Permana, A. (2017). Kepemimpinan Transformasional dan Budaya Kerja Terhadap Peningkatan Kualitas Pelayanan Pada Perusahaan Daerah Air Minum Kabupaten Sumedang (Studi Kasus Pada PDAM Tirta Medal Kabupaten Sumedang). Jurnal Ilmiah Manajemen Bisnis/Volume III, 1. 
Masambe, F., Soegoto, A. S., \& Sumarauw, J. (2015). Pengaruh Gaya Kepemimpinan, Budaya Organisasi dan Inovasi Pemimpin Terhadap Kinerja Karyawan Daihatsu Kharisma Manado. Jurnal EMBA: Jurnal Riset Ekonomi, Manajemen, Bisnis dan Akuntansi, 3(3).

Nawawi, H. 2003. Kepemimpinan Mengefektifkan Organisasi. Yogyakarta: Gajah Mada University Press.

Paramita, P. D. (2011). Gaya Kepemimpinan (Style of Leadership) yang Efektif dalam Suatu Organisasi. Dinamika Sains, 9(21).

Putri, N., Apriliani, V. D., \& Rahardjo, C. I. R. (2019). Siapa yang Tidak Menciptakan Inovasi Akan Tergilas Zaman (Dr. Fathema The Real Leader In Future Health). Universitas Ahmad Dahlan.

Resdiana, E. (2016). Kepemimpinan Inovatif dalam Peningkatan Pelayanan Publik. PUBLIC CORNER, 10(2).

Setiadi, A. (2018). Pengaruh Kepemimpinan Dan Kompetensi Aparatur Terhadap Kualitas Pelayanan Publik. Journal of Management Review, 2(2), 209-218.

Siagian, S. P. (1982). Organisasi, Kepemimpinan dan Perilaku Administrasi. Jakarta: Gunung Agung

Siagian, S. P. 2002. Fungsi-Fungsi Manajerial. Jakarta : Rineka Cipta.

Sugiyanto. (2013). Peranan Kepemimpinan Terhadap Peningkatan Kualitas Pelayanan Publik di Era Otonomi Daerah. Jurnal Mimbar Bumi Bengawan, 5(12).

Syahrian, S. (2019). Peran Kepemimpinan, Komitmen Organisasi dan Kompetensi Terhadap Budaya Organisasi Aparatur Sipil Negara Serta Implikasinya Pada Kinerja Pelayanan Publik Dinas Perdagangan dan Perindustrian Kabupaten/Kota Di Provinsi Jawa Barat. Jurnal Ilmiah MEA (Manajemen, Ekonomi, \& Akuntansi), 3(2), 150171.

Wahyudi, R. (2015). Perilaku Maladministrasi Dalam Pelayanan Publik Pasca Reformasi Birokrasi di Kota Pekanbaru, Provinsi Riau Indonesia. Jurnal Ilmu Administrasi Negara (JUAN), 3(1), 1-9.

Wirijadinata, J. J. (2020). Standar Pelayanan Publik Dalam Merealisasikan Akuntabilitas Kinerja Pemerintah. Jurnal Wacana Kinerja: Kajian Praktis-Akademis Kinerja dan Administrasi Pelayanan Publik, 10(4), 59-70.

Yukl, G. A. (1998). Leadership in Organizations (4th ed.). NJ: Prentice Hall. 